\title{
THE ONLINE LEARNING MODEL OF EDUCATION AS A COVID-19 IMPACT FOR PAUD STUDENTS: HOW TO MEASURE ITS SUCCESS?
}

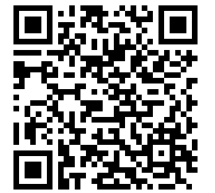

Noer Doddy Irmawati ${ }^{* 1}$ 局 (iD)

${ }^{* 1}$ Universitas Ahmad Dahlan Yogyakarta, Indonesia

DOI: https://doi.org/10.29121/granthaalayah.v8.i10.2020.1902

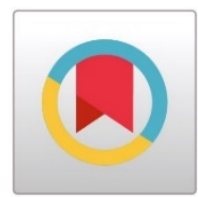

Article Type: Research Article

Article Citation: Noer Doddy Irmawati. (2020). THE ONLINE LEARNING MODEL OF EDUCATION AS A COVID-19 IMPACT FOR PAUD STUDENTS: HOW TO MEASURE ITS SUCCESS? International Journal of Research -GRANTHAALAYAH, 8(10), 157-163.

https://doi.org/10.29121/granthaa layah.v8.i10.2020.1902

Received Date: 05 October 2020

Accepted Date: 28 October 2020

Keywords:

Online Learning Model

Education

The Impact of Covid-19

Measuring the Success of Paud Students Learning from Home

\section{ABSTRACT}

The title mentioned above is discussed to overcome the difficulties of learning when facing Covid-19 for PAUD (Early Childhood Education Students) in Indonesia because they are the basic and the main level for success in Education. In fact, with the change from studying at school to learning at home, many parents face problems and difficulties, not just the teacher as a delivery of material to students and as teachers.

The changes that occur are very sudden without proper preparation, because the arrival of the covid-19 pandemic is also very sudden. However, teachers and parents are required to be able to overcome the problem of learning and education for students as the successor to the nation in order to be able to successfully achieve future achievements for their future.

The learning model is created immediately and by adjusting the situation, reality and situation. The model used is the Online and Environmental models.

Over time learning in the face of a covid-19 pandemic, is faced with a focus that needs to be overcome and must be completed simultaneously. How learning can take place well, success according to objectives, and measuring learning success are also special things that need attention. How to measure the success of online learning at home is needed, because by measuring what has been done so far through direct teacher observation it is not possible to do, because students learn at home, so the role of parents is crucial. Therefore, in this paper, it is necessary to find out how to measure the success of PAUD students in their studies at home under the supervision of parents and deal directly with the main school with the teacher.

\section{INTRODUCTION}

Talking about the Online learning model is inseparable from discussing e-Learning. Nur Hayati [1] said ELearning is media which is a very strategic instrument in determining the success of the teaching and learning process, because its existence can directly provide its own dynamics for students. Online is short for words in the network, meaning that it is a state of computers that can exchange information because it is connected to an internet, so that there is communication between teacher-students and messages delivered, there is communication, there is information obtained. Online learning can be an appropriate alternative in facing the covid-19 pandemic and simultaneously forces us to be able to master the rapidly developing electronic media today.

(C) 2020 The Author(s). This is an open access article distributed under the terms of the Creative Commons Attribution License, which permits unrestricted use, distribution, and reproduction in any medium, provided the original author and source are credited. 
Statement of Romi Satrio Wahono [2] in his lecture (2020) who said that there are components that form eLearning, such as: (1) e-learning infrastructure in the form of personal computers (PCs) / laptops, computer networks, internet and multimedia equipment. Including teleconference equipment if we provide synchronous learning services; (2) E-learning systems and applications, namely software systems that visualize conventional teaching and learning processes. How does class management, content creation, discussion forums, grading systems, online examination systems and all features related to teaching and learning management? The system is the Learning Management System (LMS). LMS is widely available open source so that elementary schools or PAUD can utilize it easily and cheaply; (3) e-learning content, i.e. the content and teaching material available in the e-learning system. This content and teaching material can be in the form of interactive multimedia or text-like content as in ordinary textbooks and can be stored in LMS so that it can be accessed by students wherever and whenever.

To be able to apply online learning / e-learning, it is necessary to know the definition of education and learning. Ki Hajar Dewantara [3] (Father of Indonesian National Education, 1889 - 1959) explained about the notion of education, namely: "Education generally means efforts to advance character (character, inner strength), mind (intellect) and physical bodies of children in harmony with nature and its people.".

Education, according to H. Horne [4], is a continuous process of higher adjustment for human beings who have developed physically and mentally, who are free and aware of needs, as manifested in the natural environment, intellectually, emotionally and as humans look and appear to be reflected by their humanity.

John Stuart Mill [5] (English philosopher, 1806-1873 AD) explained that Education includes everything that is done by someone for himself or done by others for him, with the aim of getting closer to the level of perfection.

John Dewey [6], [7] argued that education is a process of renewing the meaning of experience, this might occur in ordinary association or association of adults with young people, it might also happen intentionally and institutionalized to produce social continuity.

According to Edgar Dalle [8] that Education is a conscious effort made by the family, community, and government through the activities of guidance, teaching, and training, which take place in school and outside of school for the whole life to prepare students to be able to play a role in various environments on a permanent basis for the future.

Since the corona virus case called Covid-19 began to increase, the Government of Indonesia, Joko Widodo [9] began to quickly and responsively encourage its citizens to implement social distancing or isolate themselves at home to anticipate the spread of the virus that is increasingly widespread and raging. Schools no longer carry out activities as usual, because the government implements a system of learning activities at home.

One appropriate step in such a situation is to utilize network technology and information technology for the development of distance learning systems, namely the online learning model (in network) or online learning model (OLM) between schools and students at home (Eka Putri Melania,2020) [10]. This was done as an effort to stop the spread of the corona virus that began to spread in Indonesia. Therefore, the government (Jokowi, 2020) [11] directs the community to remain in their homes and carry out distance learning. Instructions are given to students by the teacher through online and students do it themselves with the help of parents.

With the implementation of distance learning that is using Online between the school and PAUD students in several places of course we want to know how to measure the success of students in learning to use the Online method at home which of course involves the activeness and full participation of parents for the success of their children. in study. Of course, also maintain the health of their sons and daughters so as not to be exposed to the corona virus that spread quickly and mercilessly (Piaget, 2017) [12].

\section{METHOD}

Thompson [13] revealed that Education is the influence of the environment on individuals to produce permanent changes in their behavioral habits, thoughts and nature. Affirmed by M.J. Langeveld [14] that Education is an effort, influence, protection and assistance given to children so that they are directed to maturity, or rather help children to be capable enough to carry out their own life's tasks. Education is inseparable from the learning carried 
out by the process. The ongoing learning process is inseparable from the surrounding environment. Indeed, learning is not limited to the four classroom walls. Learning with an environmental approach removes boredom and creates students to love the environment. This process involves the supervision, guidance, approach and development of the minors and the group in which they live.

One of the initiators of online learning is the Ministry of Education and Culture of the Republic of Indonesia (Nadiem, 2020) [15]. The Ministry of Education and Culture through the Directorate General of Basic Education has decided to implement the Online learning model in Indonesia in order to overcome Covid-19 and make strategies so that PAUD students can continue to learn lessons without limits and not stop formal learning activities. In addition, the function of an educator must still be there, namely carrying out their duties even in circumstances that are not possible as it is now. Teachers are required to be creative in creating learning materials, ways of learning, overcoming learning difficulties, especially at Covid-19.

\section{DISCUSSION AND RESULTS}

The aim of the online learning model is to be able to study at home to avoid an outbreak of Covid-19, prepare students who are ready to compete in the digital age, the learning process becomes more relaxed, diligently arranging deadlines for working on assignments / learning given material, sending assignments right time, more time to study. Nevertheless, the factor of boredom, boredom and decreased enthusiasm for learning remains (Yuliartiningsih, 2011) [16]. This is because students always face solitude, different when studying at school, they meet their friends, joking fun, exchanging stories that make them excited to go to school and study together at school.

The thing that I often ask is whether this online learning model is suitable for use by students in Indonesia, especially PAUD children because surely those who study or the media are their parents. Currently online learning (in networks) is carried out simultaneously in Indonesia without any preparation that is truly ripe by educators, due to the impact of Covid-19. Although there are pro and contra that arise between parents, students and educators, this method must be used (Supriatna, 2007) [17].

From the questionnaire I got an average of the constraints of online learning models in the middle of Covid-19 Pandemic - for students, especially PAUD students, is because they are weak on internet network signals, because the time applied is very short. For example, when there are meetings with teachers and students who are accompanied by parents, the time is very limited, and often also the specified time is not met in a timely manner, so communication and meetings cannot be carried out simultaneously.

The problem with the laptop problem is when the server communication error. Another obstacle, time is limited, there is no internet quota and limitations of the media used and adjustments to the financials of each person is different to deal with the situation like now (Karli and Margaretha, 2002) [18]. Another obstacle, there is still miscommunication, sometimes what the teacher explains is misunderstood by students and even parents do not understand, so students must study independently there is no collaboration in the open environment, because students work on their assignments independently.

With the current online learning model, there are several students who accept online learning, the reason being that the online learning model is more relaxed, less rushed to come to school, fun, flexible, efficient, concise, practical, fast, precise, safe, easy, saving time, saving effort (Karli and Yuliartiningsih, 2008) [19]. That way can also be done remotely without gathering in the same place, but if the implementation is too long it will be boring.

In addition, other benefits of the online learning model are that parents can supervise their children's learning, make students or teachers become tech savvy and literate, accelerate the 5.0 era, improve abilities in the field of technology (Karli and Yuliartiningsih, 2002) [20]. Students also become more creative in completing their assignments, because PAUD children are still very happy to learn with pictures, photos, films, singing, telling stories and everything that they can do in the condition of themselves as comfortable as possible to learn without formal rules 
The results of the online education and learning process from home will ultimately lead to the environment. The benefits of learning success will be felt when what is obtained from learning can be applied and implemented in the reality of life (Dahar, 2011) [21]. This is one of the positive aspects behind learning with an environmental approach.

Based on the theory of learning through an environmental approach, learning becomes meaningful, because students directly learn through what they observe, what they face, what they hear, and what they see (Nawati, 2011) [22]. The attitude of students 'verbalism toward mastery of concepts can be minimized and students' understanding will leave an imprint in their memories.

What is meant by the environmental approach is a learning strategy that utilizes the environment as a learning target, learning resources, and learning tools. This can be used to solve environmental problems and to instill an attitude of environmental love (Karli and Yuliaritiningsih, 2002) [23]. As a result of Covid-19, the closest environment to students is the house and its contents, extended family, personal facilities and infrastructure, the situation and conditions in the house, as well as all activities carried out by the family.

Learning with an environmental approach is very effective in applying in primary schools and in PAUD (Karli and Yuliartiningsih, 2011) [24]. This is relevant to the level of intellectual development of early school age (4-7 years) which is at a concrete operational stage (Piaget, in Wilis: 154) [25]. The same thing was said by Margaretha S.Y., (2002) [26] that the tendency of early school students who love to play and move causes children to prefer learning through exploration and inquiry outside the classroom.

The concepts of science and the environment around students can be easily mastered by students through observing concrete situations (Ramdhani, 2014) [27]. The positive impact of the adoption of an environmental approach is that students can be motivated by their curiosity about something in their environment. If we contemplate the four pillars of education namely learning to know (learning to know something), learning to be (learning to be who he is), learning to do (Learning to do something) and learning to life together (learning to work together) can be implemented through learning with an environmental approach that is packaged in such a way by the teacher (Piaget, 2018) [28]. Of course, the implementation at home absolutely needs the help of parents in full, consistent, and disciplined.

The impact of Covid-19 is very powerful and severe, the proof is that it can stop routine activities carried out by many people, not only in Indonesia but throughout the world. In the world of education, the impact is very detrimental and terrible in many ways such as the absence of learning activities in schools, the school becomes quiet without activities that can be done because all are afraid of contracting a painful and deadly corona virus (Gugus Tugas Percepatan Penanganan Covid-19, 2020) [29]. Ginanjar (2017) [30] added, in terms of the economy it is also very shaking the situation, circumstances and uncertainty, in terms of teachers and education personnel or human resources it is also likely that many will be affected by Covid-19 by having to give up his profession and work, in terms of students there will certainly be changes in behavior, attitudes, the nature of being confined in a home that automatically faced, there is a sense of boredom and loneliness, from the parents have a special task to accompany, educate and guide their children when learning to use online. Psychologically it is certainly very influential, there must be people who are stressed by it. Corona virus is difficult to guess what it wants, who it attacks, where it is, and when it wants to end its attack.

\section{CONCLUSIONS}

The decision of the President of the Republic of Indonesia as the Head of State by instructing the Minister of Education to stop learning activities in schools by conducting distance learning using the Online learning model is very precise, alert and fast in order to overcome the spread of the corona virus known as Covid-19. This is a preventive measure to save the Indonesian people, especially children in schools to avoid the corona virus.

The online learning model turns out to be able to break the ability of many people to give a quick respond in making changes because online learning uses activities that involve the internet with electronic media and is carried 
out at home without having to come to school. The Online learning model implemented is integrated with the Environmental Learning Model because the home environment is very varied.

Work and study that uses online and based on the surrounding environment provides added value, both for the learners themselves and for the environment, parents, siblings, teachers and anyone involved in early childhood learning. It can be said that students can study social science or learn good manners, then the social environment and surroundings can be a natural laboratory. This learning can be done while empowering social and community life, while the learner can do the learning process better and more efficiently.

In the implementation of distance learning that is from each home using the Online Learning Method combined with Environmental Based Learning has features, weaknesses and constraints.

\subsection{ITS FEATURES}

1) Students do not need to come to school but students

2) can do the assignments given by the teacher at home,

3) of course, with the guidance of parents.

4) Students gain knowledge of operating the tools needed

5) when implementing Online Learning.

6) Information obtained through the Online Learning

7) Method can be received and understood more quickly.

8) The environment strongly supports the success of

9) learning using the Environment-based Online Method.

10) The environment strongly supports the smooth

11) learning of students, because many examples can be seen and imitated and even applied in daily life.

\subsection{WEAKNESSES}

1) The cost of Electricity usage is increasing.

2) Internet facilities must be available.

3) Students cannot concentrate on learning maximally.

4) If for too long Students can get bored and even

5) stressed.

6) If the instructions and assignments given by the

7) teacher do not bind the time, students can be lazy,

8) because the work can be done at any time.

9) Difficult to measure the success of learning, because

10) students feel able to do.

\subsection{CONSTRAINTS}

1) If the power of electricity fails suddenly.

2) If the internet connection is broken.

3) Difficult to invite PAUD children to concentrate on

4) online learning for more than 10 minutes.

5) The environment must be comfortable and motivating.

6) Overcoming the boredom and tension of students who

7) are still small and have their own will.

Student learning success can be measured by their ability to explore, speak fluently, imitate experts, conduct experiments, increase their curiosity, ask lots of questions, express a lot of the results of processing their own data, can be more careful in solving problems they face, applying what is known in their everyday life, parents need to 
monitor what their children do, need to always give advice and appreciation to their children, need to reprimand and punish if they are wrong and make mistakes. There should be a good collaboration between teacher, parents and students in order the study can be successfully reached. Parents and teachers must be able to guide PAUD students who still need a lot of help.

\section{SOURCES OF FUNDING}

This research received no specific grant from any funding agency in the public, commercial, or not-for-profit sectors.

\section{CONFLICT OF INTEREST}

The author have declared that no competing interests exist.

\section{ACKNOWLEDGMENT}

I thank to this journal that will publish my manuscript. I hope and intend to contribute my thought and ideas to the reader.

I also hope that the reviewers of this manuscript will provide advice and guidance so that this manuscript can be even better. Thank you.

\section{REFERENCES}

[1] Nur Hayati. 2020 April. Metode Pembelajaran Daring/E-Learning Yang Efektif. Singaraja - Indonesia: Ganesha University Press. www.researchgate.net>publication

[2] Romi Satria Wahono. 2020. Lecture Notes in Software Engineering Computing Research and Technopreneurship. romisatriawahono.net Copyright (C) 2004-2020 RomiSatriaWahono.Net. All rights reserved.

[3] Ki Hajar Dewantoro. May 2020. 3 Fakta Ki Hajar Dewantara, Sosok di Balik Sejarah Hari Pendidikan. Bapak Pendidikan Nasional Indonesia. www.suara.com > lifestyle > male

[4] Home, H. 2016 June 19. Definition of Education. Naturalhealththy123.blogspot.com>education

[5] Mill, John Stuart (filosof Inggris, 1806-1873 M). 2019. John Stuart Mill dan Kebebasan Bicara: Bagaikan Teori. December 2019. Suarakebebasan.id > john-stuart-mill.

[6] Dewey, John--Philosopher and Educational Reformer. Educational Reform, Functional Psychology, ... accomplished by communication between citizens, experts, and politicians, with the. by K Talebi - 2015 Cited by 21 - Related articles files.eric.ed.gov > fulltext

[7] Dewey, John. 2019 - 30 August.. Approach to Education. www.thepositiveencourager.global > john-deweysapproach. Retrived from https://www.thepositiveencourager.global/john-deweys-approach-to-doingpositive- work

[8] Dale, Edgar. 2015. Applying Dale's Cone of Experience to increase learning and retention: A study of student learning in a foundational leadership course). June 2015 with 11,375 Reads DOI: 10.5339/qproc.2015. Article (PDF Available) wcee2014.6. www.researchgate.net>publication $>281505975$

[9] Joko Widodo. 2020. Jokowi Tunda Masuk Sekolah, Keluarkan Arahan Terbaru: Teka-teki kapan masuk sekolah di masa Pandemi Virus Corona atau Covid19, masih diperbincangkan. Jakarta: Presiden RI. polkrim.news. Juni 1.

[10] Eka Putri Melania. 2020 April 6. Pembelajaran Daring, Apakah Efektif Untuk Indonesia? Kompas muda https://forms.gle/WUUbFYTb8r1mczA68

[11] Jokowi. 2020. Keputusan Untuk Minta Tunda Masuk Sekolah Di Masa Pandemi Virus Corona. www.belajardirumah.org>2020/05

[12] Piaget, Jean. 2017. Model Pembelajaran Kooperatif Sebagai Upaya Penalaran. ejournal.upi.ed $>$ article $>$ view

[13] Thompson, David. 2012. Education Expert Witness, School Expert Witness, Education Program, Education Consulting Group (TECG) was founded in 2012 by Senior Partner www.edlawethics.com 
[14] Langeveld, Martinus Jan. 2016 July 16. Private Practice as an Education in Kyoto School Scholar Shuji Wada.. www.researchgate.net > publication > 300210517_Martin...

[15] Nadiem Anwar Makarim. 2020 Juni 2. Mendikbud Nadiem Makarim Akan Umumkan Mekanisme dan Syarat Pembukaan Sekolah. www.kemdikbud.go.id.

[16] Yuliartiningsih. 2011. Curriculum Based Competence and Learning Models. Bandung: Bina Media Informasi.

[17] Supriatna, Nana. 2007. Konstruksi Model Pembelajaran Cognitive. Bandung: Bina Media Informasi. Media.neliti.com>publications: 24 .

[18] Karli and S. Y. Margaretha. 2002. Implementation of Curriculum Based Competence: Learning Models. Lampung: Pustaka Universitas Lampung. digilib.unila.ac.id

[19] Karli and Yuliartiningsih. 2008. Active, Innovative, Creative, Effective and Enjoyable Learning. Tarmizi.wordpress.com>2008/11/11.

[20] Karli and Yuliartiningsih. 2002. Cooperative Learning. Surabaya: UNESA University Press.

[21] Dahar, Ratna Wilis. 2011. According to Piaget intellectual development is based on 2 functions namely organism and adaptation (135). The function of organisms. Cited by 226 - Related articles. journal.arraniry.ac.id >download

[22] Nawati, D. Y. 2011. Lingkungan Pendidikan dan Aktivitas Belajar yang Mendukung Prestasi Belajar Siswa. Semarang: Universitas Negeri Press. Lib.unnes.ac.id

[23] Karli and Yuliartiningsih. 2002. Love the Environment: Learning with an environmental approach is very effective in elementary schools. repository.upi.edu>s_tm_053974-b

[24] Karli and Yuliartiningsih. 2011. Learning with an environmental approach: Environmental learning and to instill an attitude of environmental love. gurudesaku.blogspot.com>2011/08.

[25] Piaget, Jean. 2017. Theory and Stages of Cognitive Development. www.simplypsychology.org $>$ piaget

[26] Margaretha, S. Y. 2002. Penerapan Metode Pembuatan Karikatur Dalam Pembelajaran. ejournal.upi.edu>pips>article>view

[27] Muhammad Ali Ramdhani. 2014. Lingkungan Pendidikan dalam Implementasi pada Pendidikan Karakter. Beranda. Vol.8, No.1. Copyright @ journal.uiga.ac.id 2016.Journal.uniga.ac.id>article>view

[28] Piaget Jean. 2018. Piaget's 4 Stages of Cognitive Development Explained: Theory of Cognitive Development. www.verywellmind.com>piagets-stages-of-cognitiv e-development

[29] Beranda I Gugus Tugas Percepatan Penanganan Covid-19. 2020. Informasi terbaru seputar penanganan Covid-19 di Indonesia oleh Pemerintah. covid19.go.id

[30] Ginanjar, M. H. 2017. Urgensi Lingkungan Pendidikan Sebagai Mediasi Pembentukan Karakter Peserta Didik. Jurnal. staialhidayahbogor.ac.id $>$ view 